\title{
NUTRITIONAL STATUS AFFECTS INCIDENCE OF PNEUMONIA IN UNDERFIVES
}

\author{
Henry Wicaksono \\ Health Office, District of South Halmahera \\ Community Health Center Gane Luar, District of South Halmahera
}

\begin{abstract}
ABSTRAK
Pneumonia masih menjadi penyakit infeksi akut pembunuh utama balita di dunia. Menurut Unicef, 17\% kematian anak-anak di dunia disebabkan oleh pneumonia. Indonesia menempati peringkat 10 untuk angka kematian balita karena pneumonia dan diare (29/1000 kelahiran hidup) pada tahun 2013. Hasil Riskesdas tahun 2007 menunjukkan proporsi kematian balita karena pneumonia menempati urutan kedua (13,2\%) setelah diare. Di Puskesmas Gane Luar, hampir selalu dijumpai kasus pneumonia setidaknya 3 pasien balita perbulan sepanjang tahun 2014. Beberapa faktor risiko pneumonia, yaitu angka ASI eksklusif yang rendah, malnutrisi, BBLR, cakupan imunisasi campak yang rendah, polusi udara dalam ruangan, dan kepadatan hunian yang tinggi. Penelitian ini bertujuan untuk mengetahui hubungan antara pemberian ASI eksklusif, status gizi, dan jenis lantai rumah terhadap kejadian pneumonia pada balita di wilayah kerja Puskesmas Gane Luar, Halmahera Selatan. Metode yang digunakan yaitu observasional analitik dengan studi kasus kontrol. Sampel diambil dengan teknik simple random sampling selama 6 bulan (Juli-Desember 2014), yaitu sebanyak 25 balita pada sampel kasus dan 25 balita pada sampel kontrol. Data dikumpulkan dengan wawancara menggunakan kuesioner, observasi, dan pemeriksaan fisik, kemudian dianalisis dengan metode Regression Binary Logistic, Chi Square, dan Odds ratio (CI 95\%) untuk mengetahui kekuatan hubungan antar variabel. Hasil penelitian menunjukkan bahwa terdapat hubungan bermakna antara status gizi $(p=0,019$; OR 3,795) terhadap kejadian pneumonia, namun variabel ASI eksklusif $(p=0,29)$ dan jenis lantai rumah $(p=0,086)$ tidak memiliki hubungan bermakna. Disimpulkan bahwa terdapat hubungan bermakna antara status gizi terhadap kejadian pneumonia pada balita di wilayah kerja Puskesmas Gane Luar, Halmahera Selatan.(FMI 2015;51:285-291)
\end{abstract}

Kata kunci: pneumonia, ASI eksklusif, status gizi, jenis lantai rumah, balita, faktor risiko, kasus kontrol.

\begin{abstract}
Pneumonia is an acute infection disease which remains the main killer of children under 5 years old worldwide. Based on Unicef's report, $17 \%$ of all children death is caused by pneumonia. Indonesia was in 10th position of the highest incidence of pneumonia and diarrhea which caused the death of children under 5 years old in 2013. In Gane Luar Public Health Center, there were at least 3 patients with pneumonia every month during 2014. The risk factors are less exclusive breastfeeding, malnutrition, low birth weight, less coverage of measles vaccine, indoor air pollution, and the high level of occupation density. The purpose of this research was to determine the relationship between exclusive breastfeeding, nutrition status, the type of house flooring, and pneumonia incidence in children under 5 in working area of Gane Luar Public Health Center, South Halmahera. A case control study was conducted to each 25 samples of case and control which were collected by simple random sampling technique during July-December 2014. Data were collected through a questionnaire using interview method, observation, and physical examination, and then it's analyzed by Regression Logistic, Chi Square, and Odds ratio to check for strength of association between variables at 95\% confidence level. The results indicated that nutrition status was significantly related to Pneumonia incidence $(p=0.019$; OR 3.795), however exclusive breastfeeding $(p=0.29)$ and type of house flooring $(p=0.086)$ weren't. In conclusion, the nutrition status was significantly related to the incidence of Pneumonia in working area of Gane Luar Public Health Center. (FMI 2015;51:285-291)
\end{abstract}

Keywords: pneumonia, exclusive breastfeeding, nutrition status, type of house flooring, children under 5 years old, risk factor, case control.

Correspondence: Henry Wicaksono, Jalan Sunandar Priyosudarmo V/18 Sidoarjo 61214, Indonesia.

Phone: 082347981556. Email: henrywicaksono@yahoo.com

\section{INTRODUCTION}

Pneumonia is an acute infection disease that attacks lung's alveoli and caused signs and symptoms including cough and or difficulty of breathing, inferior chest retraction, and supported by x-ray image of acute lung infiltrate (Direktorat Jendral Pengendalian Penyakit dan Penyehatan Lingkungan 2013). Globally, pneumonia remains the main killer of children under 5 years old which caused $17 \%$ of death in children worldwide in 2004 and it increased to $20 \%$ or 1,8 million in 2007 (Unicef 2009). It is reported that the incidence of childhood pneumonia is only $0.02 \%$ to $0.38 \%$ episodes per child-year among children under 5 years old in Norway, USA, Finland, Scotland and UK, while it was reported that to be $6 \%-27 \%$ episodes per child-year among 
children under 5 years in China. This disease predominantly affects developing countries more than developed country and is highly concentrated in just a few countries.

Indonesia itself as a developing country was in 10th position of the highest incidence of death in children under 5 years old (29 of 1000 birth) due to pneumonia and diarrhea in 2013 (Table 1) (International Vaccine Access Center 2013). According to Indonesia Basic Health Research's report in 2013, the rate incidence and prevalence of pneumonia were $1.8 \%$ and $4.5 \%$ (Report of Basic Health Research (Riset Kesehatan Dasar/ Riskesdas) (2013)). In 2007, proportion of death in children under 5 years old because of pneumonia took second place after diarrhea (Report of Basic Health Research (Riset Kesehatan Dasar/Riskesdas) (2013)). In North Maluku province, prevalence of pneumonia was $0.8 \%$ in 2013 (Report of Basic Health Research (Riset Kesehatan Dasar/Riskesdas) (2013)). In Public Health Center of Gane Luar, South Halmahera, there were at least 3 patients of pneumonia every month during 2014 according to a monthly report.

Based on the highest period prevalence of age characteristic, pneumonia often attacks children of group age 1-4 years old (Report of Basic Health Research (Riset Kesehatan Dasar/Riskesdas) (2013)). The risk factors of pneumonia are including less exclusive breastfeeding, malnutrition, low birth weight, less coverage of measles vaccine, indoor air pollution, and the high level of occupation density (Direktorat Jendral Pengendalian Penyakit dan Penyehatan Lingkungan 2013). The purpose of this research was to determine the relationship between exclusive breastfeeding, nutrition status, type of house of flooring, and the incidence of pneumonia in working area of Public Health Center of Gane Luar, South Halmahera (figure 1,2,3).

\section{MATERIALS AND METHODS}

A case control analytical study was conducted during July-December 2014 in villages of working area of Gane Luar Public Health Centre, South Halmahera. Population was all children under 5 years old. Inclusions criteria of case group were children under 5 years old whom diagnosed pneumonia by the doctor and their mother whom intended to participate in this research. Inclusions criteria of control group were healthy children under 5 years old and their mother whom intended to participate. On the contrary, exclusions criteria were the mothers that had either children under 5 years old whom got pneumonia (case) or were the healthy ones (control) that refused to participate.

Table 1. Global mortality rank in pneumonia \& diarrhea deaths in children under 5

\begin{tabular}{clc}
\hline $\begin{array}{c}\text { Global Mortality } \\
\begin{array}{c}\text { Rank in Pneumonia } \\
\text { \& Diarrhea Deaths in } \\
\text { Children Under 5 }\end{array}\end{array}$ & Countries & $\begin{array}{c}\text { Pneumonia \& Diarrhea } \\
\text { Deaths in Children } \\
\text { Under 5 Years } \\
\text { (in 1000s) 2013 }\end{array}$ \\
\hline 1 & India & 436 \\
2 & Nigeria & 231 \\
3 & Democratic Republic of the Congo & 121 \\
4 & Pakistan & 111 \\
5 & Ethiopia & 62 \\
6 & China & 50 \\
7 & Angola & 48 \\
8 & Afghanistan & 33 \\
9 & Niger & 29 \\
$\mathbf{1 0}$ & Indonesia & $\mathbf{2 9}$ \\
11 & Kenya & 28 \\
12 & Mali & 26 \\
13 & Uganda & 25 \\
14 & United Republic of Tanzania & 21 \\
15 & Burkina Faso & 18 \\
\hline
\end{tabular}

(International Vaccine Access Center 2013) 


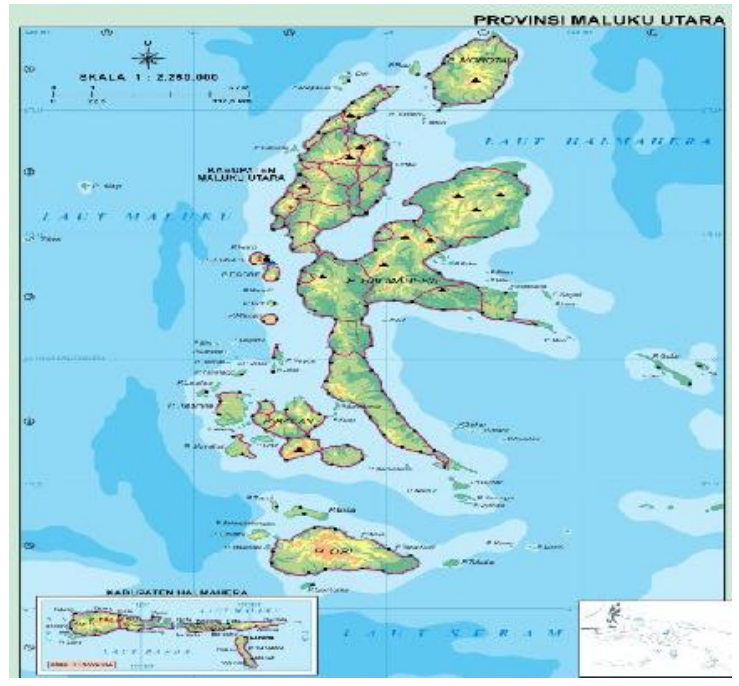

Figure 1. Map of North Maluku Province

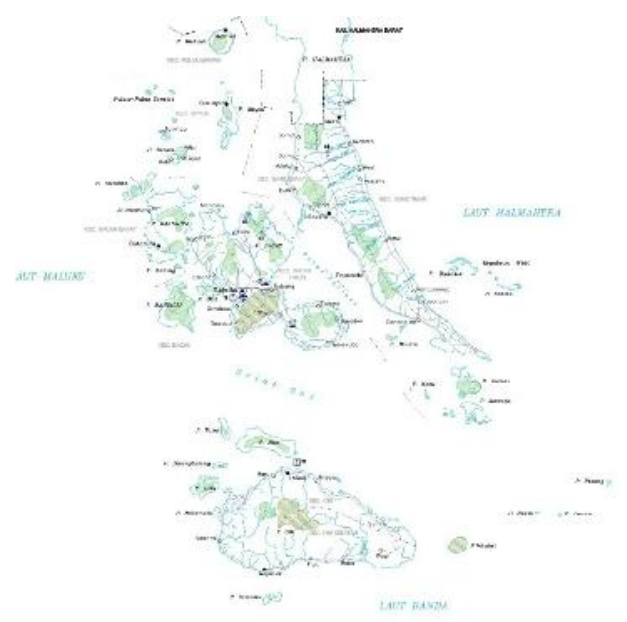

Figure 2. Map of South Halmahera Regency

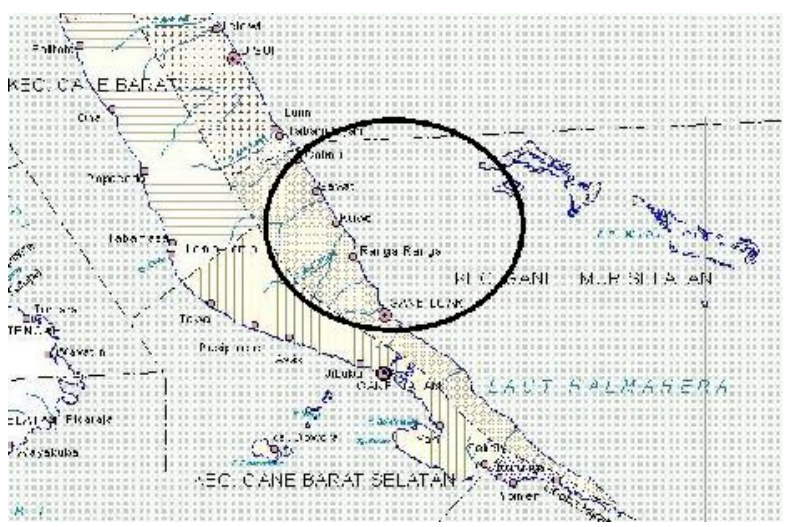

Figure 3. The five villages of working area of Gane Luar Public Health Center 
Simple random sampling technique was applied and 50 samples of children under 5 years old which contained of 25 samples of case and 25 samples of control were collected after being selected according to inclusion and exclusion criteria until the desired sample size was attained based on the formula of case control minimum sample size. Data were collected through a structured questionnaire using face to face interview method to find out about exclusive breastfeeding, observation to check the type of house flooring, and physical examination to find out about anthropometric data for nutrition status and to diagnose pneumonia. A Z-score criteria was used to establish children nutrition status after anthropometric data collected. Meanwhile, a WHO criteria was used to diagnose pneumonia in children. Analysis of data collected was done using the SPSS statistical package version 17.0. The Regression Logistic, Chi Square, and Odds ratio were used to check for strength of association between variables at $95 \%$ confidence level.

\section{RESULTS}

Table 2 shows that either case or control group had each 25 samples which contained of 8 girls under 5 years old and 17 boys under 5 years old. Most of the respondents were both equally in group age 0-12 months and 13-24 months which had percentage $36 \%$. Table 3 shows the frequency distributions of case and control according to these variables.

After putting collecting data into SPSS 17.0 and analyzed with Regression Binary Logistic and Chi Square, the output was shown in Table 3. The interaction between exclusive breastfeeding-type of house flooring and the incidence of pneumonia was apparently insignificant ( $p>0.05)$. Meanwhile, nutrition status was closely related to incidence of pneumonia. The odds ratio of nutrition status was 13,782 . It meant that children under 5 years old with malnutrition-underweight were 13,872 times likely to get pneumonia than were those who had a good-overweight nutrition status.

Table 2. Socio-demographic characteristics of the study subjects $(n=50)$

\begin{tabular}{lccccc}
\hline \multirow{2}{*}{$\begin{array}{l}\text { The characteristics of children under } \\
\text { 5 years old }\end{array}$} & \multicolumn{4}{c}{ Subjects } \\
\cline { 3 - 6 } & & Case & Control \\
\cline { 3 - 6 } & Girl & 8 & 32 & 8 & $\%$ \\
\hline Sex & Boy & 17 & 68 & 17 & 68 \\
\hline Total & & 25 & 100 & 25 & 100 \\
\hline Age (months) & $0-12$ & 9 & 36 & 9 & 36 \\
& $13-24$ & 9 & 36 & 9 & 36 \\
& $25-36$ & 2 & 8 & 2 & 8 \\
& $37-48$ & 3 & 12 & 3 & 12 \\
& $49-60$ & 2 & 8 & 2 & 8 \\
\hline Total & & 25 & 100 & 25 & 100 \\
\hline
\end{tabular}

Table 3. Numbers (percentage) of cases of pneumonia and controls according to main risk factors

\begin{tabular}{lcc}
\hline \multicolumn{1}{c}{ Risk Factors } & Cases $(\mathrm{n}=25)$ & Control $(\mathrm{n}=25)$ \\
\hline Exclusive breastfeeding & $2(8)$ & $3(12)$ \\
Yes & $23(92)$ & $22(88)$ \\
No & & \\
Nutrition Status & $15(60)$ & $24(96)$ \\
Good-overweight & $10(40)$ & $1(4)$ \\
Malnutrition-underweight & & \\
Type of house flooring & $16(64)$ & $10(40)$ \\
Sand & $9(36)$ & $15(60)$ \\
Not sand &
\end{tabular}

Table 4. Results of multiple analyses using Regression Logistic Test

\begin{tabular}{cccc}
\hline Risk Factors & p value & OR & \multicolumn{1}{c}{ CI 95 \% } \\
\hline Exclusive breastfeeding & 0.290 & 3.795 & $0.321-44.919$ \\
Nutrition status & 0.019 & 13.872 & $1.531-125.694$ \\
Type of house flooring & 0.086 & 3.235 & $0.848-12.335$ \\
\hline
\end{tabular}




\section{DISCUSSION}

\section{Exclusive breastfeeding-pneumonia}

Basically the low rate of exclusive breastfeeding is one of the most important risk factor of pneumonia incidence (César et al 1999). Exclusive breastfeeding is defined as giving an infant only breastfeeding without any other additional fluid or solid-semi solid food, such as formula milk, mineral water, tea, banana, papaya, and biscuit at least during the first six months (Anggrita 2009). The American Academy of Pediatrics in conjunction with the World Health Organization, strongly recommends that infants receive breast milk solely through the first 6 months of life and continue to receive breastmilk with complementary foods through at least the first year of life (Fulhan 2006). Moreover, giving solid-semi solid food too early can be one of the risk factor of aspiration pneumonia.

Breastfeeding contains of immunoglobulin which is as the most perfect immunity system for infants to protect from all kind of bacteria and virus infection. The main component of breastfeeding that has a function for protection against infection is whey protein. Whey contains of lactoferin, Ig A secretory, lysozyme, and bifidus factor. Therefore, infants who are breast fed supposed to have a better immunity condition among infants who weren't being breast fed (Story \& Parish 2008).

In this research, there was no significant association between breastfeeding and pneumonia $(p=0.29)$. This result was on the contrary with the previous research from César et al in Pelotas, Brazil in 1999 which was also a case control study. Taking 152 case samples of 28 days-1 year old infant admitted in hospital with pneumonia and 2391 control samples, the research concluded that the risk of admission for pneumonia was 17 times greater among infants who were not being breast fed. Even for children who received both maternal and formula milk, the risk was about four times greater than that for children who received breast milk alone. This marked dose-response effect, along with the biological plausibility of a link between breastfeeding and pneumonia, is strongly supportive of a causal association (César et al 1999).

Compared to that research, the differentiation of sample size could be the reason why there was no significant association between breastfeeding and pneumonia in this research although it had attained the minimum sample size according to the statistic formula of case control study. The fact in the field actually showed that the rate of exclusive breastfeeding in working area of Gane Luar Public Health Center either in case sample or control was quite low. It was consecutively only $8 \%$ and $12 \%$. That fact could be one of the factors too why there was no significant association between breastfeeding and pneumonia. The low level of major mother education in this area was the possibility cause why the rate of exclusive breastfeeding was very low. During the face to face interview with the mothers, there were statements that showed the less understanding about exclusive breastfeeding. They said that breastfeeding was never enough considering their baby continued crying and giving solid-semi solid food early could make their gastrointestinal track stronger. Giving a regular and continuous education and health promotion are needed to make their understanding about exclusive breastfeeding better.

\section{Nutrition status-Pneumonia}

Mortality due to childhood pneumonia is strongly linked to malnutrition (Unicef 2009). Malnutrition is the primary cause of immunodeficiency worldwide. There is a strong relationship between malnutrition and infection and infant mortality. Poor nutrition will leave children underweight, weakened, and vulnerable to infections, primarily due to the epithelial integrity and inflammation (Katona \& Katona-Apte 2008). In malnutrition, immunity mediator cell, complement system, and Ig A secretor have changed into less number. Those will make humoral immunity vulnerable. There is disruption of epithelial regeneration in respiratory tract. Thymus gland and tonsil get so atrophy that the number of t-lymphocyte decreases gradually. Those are why the deficiency of cellular immunity occurs then it will make the infection process continues easily.

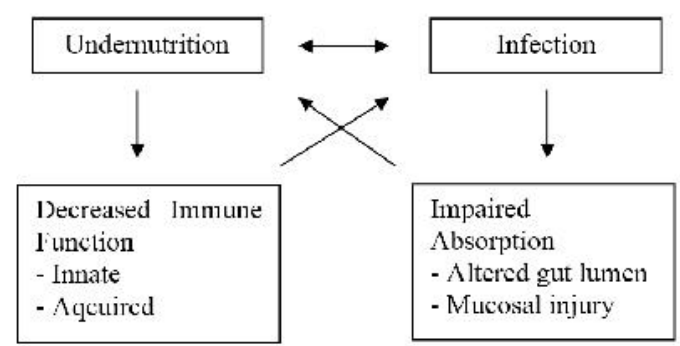

Figure 4. Interaction between malnutrition and infection (Katona \& Katona-Apte 2008)

It's not only malnutrition which can make a person more susceptible to infection, but also it's the infection that also can contribute to malnutrition, which cause a vicious cycle (Katona \& Katona-Apte 2008). The severity and long duration of infection will lead to appetite loss and malabsorption which cost an adequate dietary intake. That is why infection can cause malnutrition in the end. 


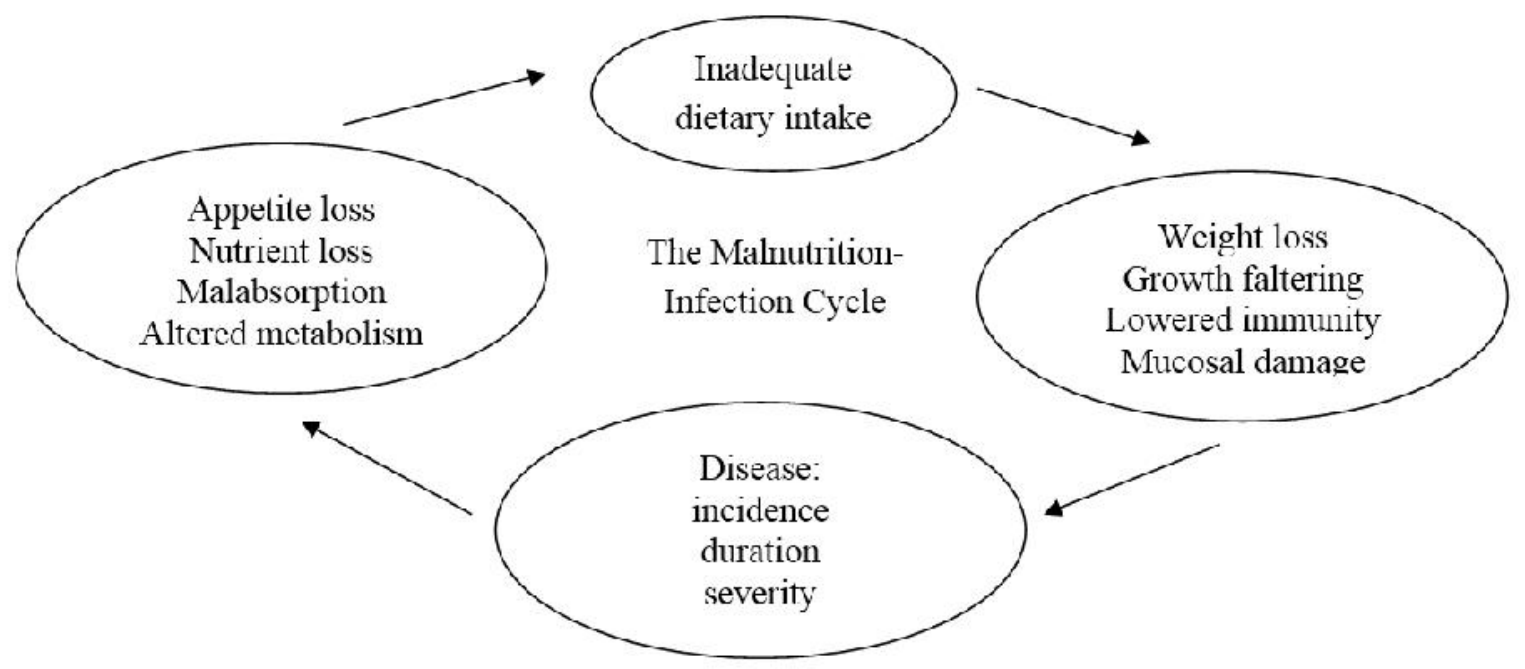

Figure 5. The "vicious cycle" of malnutrition and infection (Katona \& Katona-Apte 2008)

In this research, nutrition status was significantly related to Pneumonia incidence ( $p=0.019$; OR 13,872). It meant that children under 5 years old with malnutritionunderweight were 13,872 times greater to get pneumonia than were those who had a good-overweight nutrition status.

This had same result as the research of Caulfield et al (2004) where they concluded that children under 5 years old with malnutrition-underweight based on a Z-score were 8.09 times greater to get pneumonia than were those who had a good-overweight nutrition status (Caulfield et al 2004). So because malnutrition is considered a key risk factor for pneumonia, maintaining good nutritional status must be done to prevent the infection (Tomkins \& Watson 1993).

\section{Type of house flooring-pneumonia}

Type of house flooring which becomes one of the risk factor of pneumonia here is a sand floor. The floor still made of sand makes the condition of the house more humid. Eventually, that condition becomes more favorable for bacteria, virus, and fungi to grow rapidly (Yuwono 2008). On the contrary, in dry season, the house will be filled with so much dust that will create indoor pollution in the house. Beside those, most people in Gane Luar actually have a bad habit when they get cough. They will directly spit out the sputum just right there at the moment where they are. If they do that in sand floor inside the house, the spread of bacteria will get more massive and can contaminate the children easily.

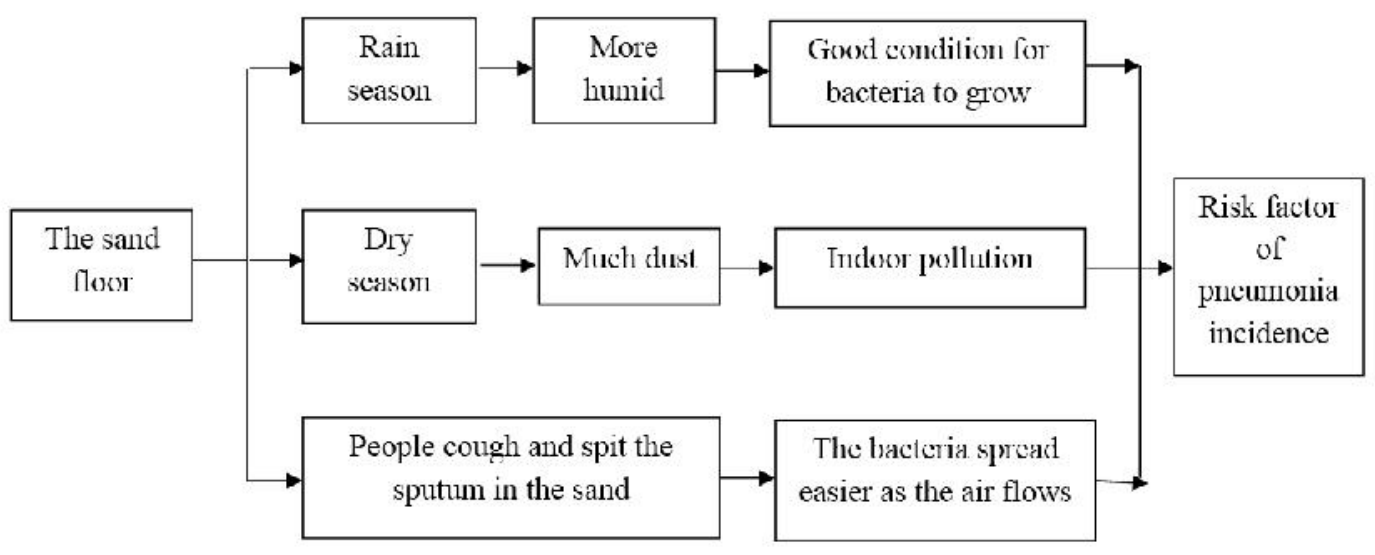

Figure 6. The mechanism of how sand floor can be one of the risk factors of pneumonia incidence 
In this research, there is no significant association between the type of house flooring and incidence of pneumonia. This result is the opposite of the research of Yuwono in working area of Kawunganten Public Health Center, Cilacap in 2008. In that research which was also a case control study, it concluded that children under 5 years old who lived in sand floor were 3.9 times higher to get pneumonia than were those who didn't live in sand floor (Yuwono 2008).

\section{Research Limitations}

Case control study actually has some limitations, especially a recall bias. It often occurred when respondents were asked to provide some retrospective information about the history of exclusive breastfeeding in this case. Therefore, the structured questionnaire had been made as simple as possible. The questions included whether mother knew the exact definition of exclusive breastfeeding and whether mother gave a substitution food or fluid beside breastfeeding to the baby during first six months. Despite the structured questionnaire, the recall bias remains exist considering the limitations of mother's memory.

Basically, the Public Health Center of Gane Luar has 5 villages of working area. There are Gane Luar, RangaRanga, Kuwo, Sawat, and Gaimu (Figure 3). Due to the limitations of human resources, distance, and time, the samples couldn't be taken from all villages. This research actually could have had more representative sample size. Theoretically, there are many risk factors of pneumonia besides exclusive breastfeeding, nutrition status, and type of house flooring, including low birth weight, less coverage of measles vaccine, indoor air pollution, the level of occupation density, family member smoking, immunodeficiency condition, and lack of ventilation. Due to the limitation of human resources and time, those couldn't be included in this research.

\section{CONCLUSION}

In summary, nutrition status had a significant association to pneumonia incidence in children under 5 years old in working area of Gane Luar Public Health Center. Intervention action to prevent and manage undernutrition children must be applied to be one of the solutions to decrease the risk of pneumonia incidence. Meanwhile, exclusive breastfeeding and type of house flooring did not have any significant association to pneumonia incidence.

\section{REFERENCES}

Anggrita K (2009). Hubungan karakteristik ibu menyusui terhadap pemberian ASI eksklusif di wilayah kerja puskesmas Medan Amplas. Bachelor Thesis. Universitas Sumatera Utara, Medan, p 5

Caulfield LE, de Onis M, Blössner M, Black RE (2004). Undernutrition as an underlying cause of child deaths associated with diarrhea, pneumonia, malaria, and measles. Am J Clin Nutr 80, 193-198

César JA, Victora CG, Barros FC, Santos IS, Flores JA (1999). Impact of breast feeding on admission for pneumonia during postneonatal period in Brazil: nested case-control study. BMJ 318, 1316-1320

Direktorat Jendral Pengendalian Penyakit dan Penyehatan Lingkungan 2013. 'Pedoman Pengendalian Infeksi Saluran Pernafasan Akut', Kemenkes RI, Jakarta, pp. vii,1,5, 14, 15.

Fulhan, Kostka J (2006), 'Breastfeeding'. In: Manual of Pediatric Nutrition. Third Edition , p. 86.

International Vaccine Access Center (2013). Pneumonia and Diarrhea Progress Report 2013, Baltimore, Johns Hopkins Bloomberg School of Public Health, p 6

Katona P and Katona-Apte J (2008). The interaction between nutrition and infection. Clin Infect Dis 46, 1582-1588

Ministry of Health Republic of Indonesia (2013). Report on Result of National Basic Health Research (RISKESDAS 2013), Jakarta, Departemen Kesehatan Republik Indonseia, p 9 and 101

Story L and Parish T (2008). Breastfeeding helps prevent two major infant illness. The Internet Journal of Allied Health Sciences and Practice 6

Tomkins A and Watson F (1993). Nutrition Policy Discussion Paper. Switzerland: World Health Organization. Available from http://www.unscn.org/ layout/modules/resources/files/Policy_paper_No_5.pd f. Accessed February 5, 2014, p 8

Unicef (2009). Pneumonia-the number 1 killer of young children. Global Action Plan for Prevention and Control of Pneumonia (GAPP), p 5

Yuwono TA (2008). Faktor-faktor lingkungan fisik rumah yang berhubungan dengan kejadian pneumonia pada anak balita di wilayah kerja puskesmas Kawunganten kabupaten Cilacap. Master Thesis. Universitas Diponegoro, Semarang, p 65-73 